\title{
Additions and Corrections. Critical Perspective: Named Reactions Discovered and Developed by Women
}

Julie A. Olsen

Smith College

Kevin M. Shea

Smith College, kshea@smith.edu

Follow this and additional works at: https://scholarworks.smith.edu/chm_facpubs

Part of the Chemistry Commons

\section{Recommended Citation}

Olsen, Julie A. and Shea, Kevin M., "Additions and Corrections. Critical Perspective: Named Reactions Discovered and Developed by Women" (2012). Chemistry: Faculty Publications, Smith College, Northampton, MA.

https://scholarworks.smith.edu/chm_facpubs/12 
Additions and Corrections. Critical Perspective: Named Reactions Discovered and Developed by Women $^{1}$

Julie A. Olson and Kevin M. Shea

\section{New Information on Reactions not Described Previously}

Professor Gerald Dyker informed us about another reaction unambiguously named for a woman. The Catellani reaction is named for Professor Marta Catellani from the University of Parma in Italy. Catellani earned her PhD at the University of Parma in 1971 and is currently a full professor and director of the Department of Organic and Industrial Chemistry.

In 1997, Catellani reported the multicomponent coupling of an aryl iodide, an alkene, and two equivalents of an alkyl iodide in the presence of norbornene and a palladium catalyst to yield three new carbon-carbon bonds to the benzene ring. For example, the Catellani reaction of iodobenzene (1), methyl acrylate (2), and $n$-butyliodide (3) provides 1,2,3-trisubstituted benzene 4 in $93 \%$ yield. $^{2}$

\section{Scheme 1}

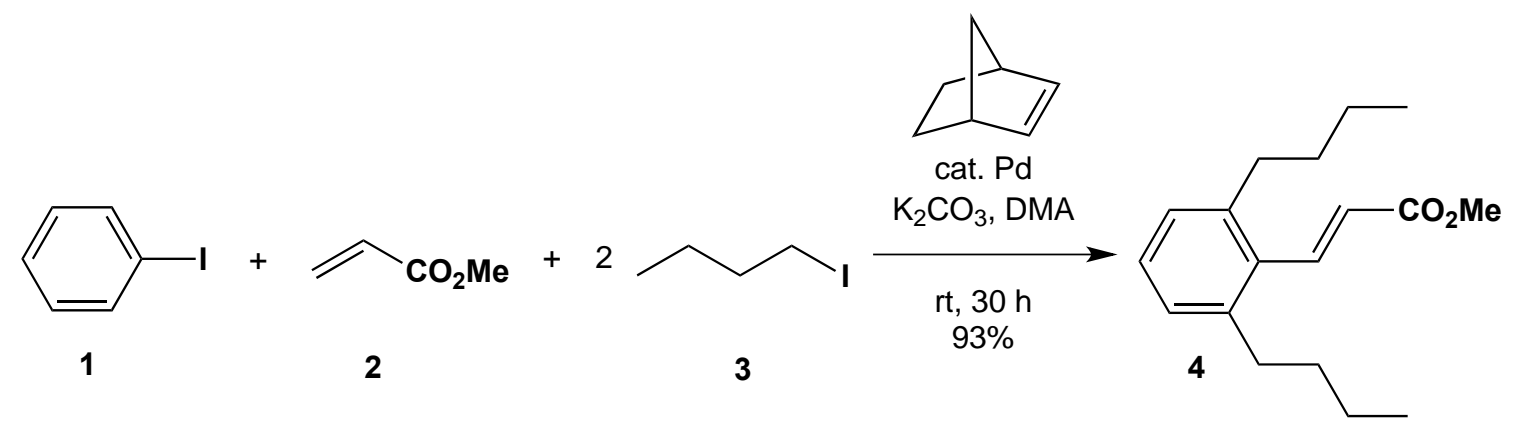

Howard Zimmerman informed us about the origin of the well-known Zimmerman-Traxler transition structure for the reaction of enolates with carbonyls. Although not a named reaction, the Zimmerman-Traxler transition structure is more widely used than many named reactions and merits inclusion here due to its enduring utility.

Marjorie Traxler, an undergraduate at Northwestern University, joined Zimmerman's research lab in 1954, soon after he began his independent career. Traxler investigated the stereochemistry of the Ivanov and Reformatsky reactions, and, in 1957, Zimmerman and Traxler published their transition structure to explain the stereochemical outcome of the Ivanov reaction. ${ }^{3}$ They proposed a chair-like transition structure involving chelation to magnesium to rationalize the preference for anti versus syn products. As depicted below, reaction of benzaldehyde (5) with enolate $\mathbf{6}$ proceeds through transition structure $\mathbf{7}$ to furnish anti product 8 . 


\section{Scheme 2}

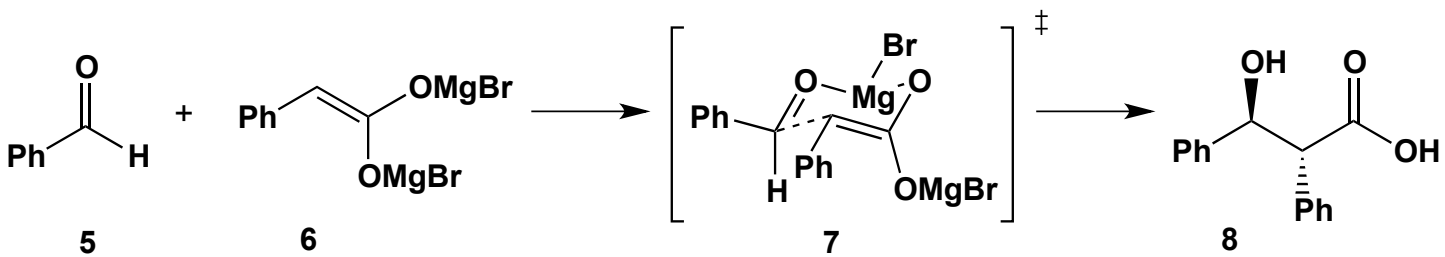

After graduating from Northwestern, Traxler became a Fulbright Fellow and studied organic chemistry in Germany at the University of Frankfurt. She then earned a masters degree from Stanford University and taught chemistry at several Chicago area colleges and universities. Alschuler, her married name, returned to Northwestern and earned a Ph.D. in science education in 1974 and spent the next 30 years as a medical educator.

\section{Corrections}

We were in error in indicating that the procedures for the conversion of $\mathbf{2 6}$ to $\mathbf{2 8}$ in Scheme $9^{1}$ were first published in 1969 by Felix et al. ${ }^{4}$ It was pointed out to us by Professor Eschenmoser that this reaction was originally discovered by Alexander Wick and that full experimental details for this conversion can be found in his 1964 Ph.D. thesis. ${ }^{5}$

Professor William Roush noted two errors in the section focused on his research with Kaori Ando. First, the reaction named for Roush is the "Roush Asymmetric Allylation" not the "Roush Asymmetric Alkylation". Second, Roush was a faculty member at "Indiana University" not "the University of Indiana".

\footnotetext{
${ }^{1}$ Olson, J. A.; Shea, K. M. Critical Perspective: Named Reactions Discovered and Developed by Women Acc. Chem. Res. 2011, 44, 311-321.

${ }^{2}$ Catellani, M.; Frignani, F.; Rangoni, A. A Complex Catalytic Cycle Leading to a Regioselective Synthesis of $o, o^{\prime}-$ Disubstituted Vinylarenes Angew. Chem. Int. Ed. 1997, 36, 119-122.

${ }^{3}$ Zimmerman, H. E.; Traxler, M. D. The Stereochemistry of the Ivanov and Reformatsky Reactions. I J. Am. Chem. Soc. 1957, 79, 1920-1923.

${ }^{4}$ Felix, D.; Gschwend-Steen, K.; Wick, A. E.; Eschenmoser, A. Claisen Rearrangement of Allyl and Benzyl Alcohols with 1-Dimethylamino-1-methoxyethene Helv. Chim. Acta 1969, 52, 1030-1042.

${ }^{5}$ Wick, A. E. Untersuchungen in Richtung einer Totalsynthese von Vitamin B12. Ph.D. Thesis, ETH Zürich, 1964. Nr. 3617; www.e-collection.ethbib.ethz.ch
} 